\title{
¿Puede Alack Sinner ser feliz? Breve ensayo sobre la felicidad a través de un personaje de cómic
}

\author{
Argelio García
}

Argelio García es biólogo, ha escrito artículos sobre cómic en El Diario de Avisos de Tenerife y en Tebeolandia. Desde 1983 es miembro del jurado de los Premios de la Historieta de El Diario de Avisos.

Fecha de recepción: 29 de mayo de 2016

Fecha de aceptación definitiva: 3 de noviembre de 2016 


\title{
Resumen
}

Alack Sinner es uno de los personajes más atormentados del cómic. El trauma de crecer en una familia rota, la participación en un conflicto bélico y su baja resiliencia le hacen ser un hombre emocionalmente inestable. En este artículo se analiza la vida de Alack Sinner a través de los acontecimientos y de los personajes que han contribuido a su felicidad o a su desgracia. Para ello se examina las figuras materna y paterna y aspectos personales como la salud, la religión, los ideales políticos, el trabajo, la soledad, el amor o la paternidad desde el punto de vista de la felicidad.

Palabras claves: cómic, bandes dessinées, José Muñoz, Carlos Sampayo, felicidad.

\begin{abstract}
Alack Sinner is one of the most tormented comic characters. The trauma of growing up in a broken family, fighting in a war, and his low psychological resilience, make him an emotionally unstable man. This essay speaks about Alack Sinner's life through events and characters that have contributed to his happiness or misfortune. His mother and father figures, along with personal aspects like health, religion, political ideals, job, loneliness, love and paternity are examined.
\end{abstract}

Keywords: comic, bandes dessinées, José Muñoz, Carlos Sampayo, happiness.

\section{Cita bibliográfica}

García, A. «¿Puede Alack Sinner ser feliz? Breve ensayo sobre la felicidad a través de un personaje de cómic», en CuCo, Cuadernos de cómic n.o 7 (2016), pp. 110-135. 


\section{Introducción}

La felicidad es un concepto abstracto que nadie puede definir con precisión porque cada individuo la percibe de distinto modo, además «el significado de la felicidad cambia en una misma persona con el paso del tiempo». ${ }^{1}$

El pesimismo radical del filósofo Schopenhauer nos advierte de que la felicidad es una meta inalcanzable, que la vida de los seres humanos oscila entre dolor y aburrimiento y que solo podremos alcanzar una felicidad relativa que consiste en la ausencia de dolor. ${ }^{2}$

Sin duda, la existencia está llena de desgracias que son inevitables pero también tenemos la posibilidad de construir un particular sentido de la felicidad a partir de un estado de ánimo real y congruente con las ganas de vivir.

Las situaciones dolorosas se pueden trabajar y llegar a superar, incluso se puede recuperar a personas que han sufrido un trauma emocional como muestran los trabajos sobre la resiliencia. ${ }^{3}$

Investigaciones en el campo de la psicología positiva llevadas a cabo por Sonja Lyubomirsky concluyen que el $50 \%$ del nivel de felicidad de una persona viene determinado por su material genético, que el 10\% lo dictan las circunstancias de la vida y que solo el $40 \%$ depende de las acciones individuales para ver las cosas de forma positiva. ${ }^{4}$

Aunque el margen que tiene un individuo para intervenir en el logro de su felicidad no es muy alto, es suficiente para equilibrar la balanza del bienestar a su favor.

1 Rojas Marcos, L. Nuestra felicidad. Madrid, Espasa Calpe, 2000, p. 87.

2 Schopenhauer, A. El arte de ser feliz. Barcelona, Herder editorial, 2012.

3 La resiliencia es el término divulgado por el psiquiatra e investigador Boris Cyrulnik que indica «la capacidad de la vuelta a la vida tras pasar por un trauma». Cyrulnik, B. «Nadie sabe definir la felicidad», en El País, (Abril, 2016). Disponible en http://elpais.com/elpais/2016/03/22/actualidad/1458665067 836852.html

4 Manes, F. «La felicidad de todos los días» en El País, (Marzo, 2016). Disponible en http://elpais.com/ elpais/2016/03/20/ciencia/1458473642 576776.html 


\section{Alack Sinner, un personaje trágico}

En 1974, la revista italiana Alterlinus publicó el primer episodio, «El caso Webster», de la serie de cómic de Alack Sinner. La obra continuaría publicándose hasta el año 2006 con la aparición del último libro: «El caso USA».

Ejecutadas con dibujos expresionistas, en blanco y negro, las peripecias de Alack Sinner tenían en sus inicios todos los ingredientes de una obra del género policiaco, pero luego evolucionarían hasta convertirse en un drama intimista dando lugar a uno de los personajes más atormentados de la historia del comic. ${ }^{5}$

El estilo narrativo es en primera persona, lo que permite conocer los pensamientos e ideas del protagonista y facilita el análisis psicológico. En algunos episodios de la serie se pierde este estilo narrativo y en «El caso USA» el propio Alack Sinner nos advierte de que «ya no leo los pensamientos de los demás y no sigo sus aventuras cuando no los veo».

A la hora de elegir el nombre del personaje, Carlos Sampayo (guionista) encontró una expresión muy antigua en un diccionario cockney: Alack and alas (pobre de mî); José Muñoz (dibujante) había escuchado esta expresión a una vieja dama inglesa. ${ }^{6} \mathrm{El}$ apellido Sinner se impuso de forma natural, de modo que el nombre completo, Alack Sinner (pobre de mí, pecador), presagiaba que los padres/autores habían dotado a su personaje de un «material genético» poco proclive para que su vida fuera feliz; además, dado que las «circunstancias de la vida» a las que Alack Sinner iba a ser expuesto no reunían muchos elementos dignos para fomentar la felicidad, solo le quedaban las «acciones individuales» para reclamar su derecho a ser feliz. ${ }^{7}$

Dado el planteamiento intelectual de la obra y su estilo narrativo, cabía la posibilidad de preguntarnos: ¿puede Alack Sinner ser feliz? ¿Le dejaron sus padres/autores algún resquicio por el que pudiera escaparse al triste destino al que estaba predestinado? Las respuestas a estas preguntas son el objeto de este trabajo.

\section{El contexto temporal}

El contexto histórico en el que se desarrollan los episodios de la obra va desde el ataque a la base naval de los Estados Unidos en Pearl Harbour (Hawaii) por la Armada Imperial japonesa, el 7 de diciembre de 1941, hasta el año 2004, tres años después de la destrucción

\footnotetext{
5 Reggiani, F., \& Von Sprecher, R. H. «Alack Sinner: un detective degenerado», en Tebeosfera. Disponible en http://www.tebeosfera.com/documentos/documentos/alack_sinner_un_detective_degenerado.html

6 Lemare, T. «Muñoz: Un argentin en noir et blanc», en Zoo, n.o 11 (2008), p. 7.

7 La literatura o los medios de comunicación, generalmente, se hacen eco de relatos y hechos turbulentos ya que son los que atraen la atención del público. La vida cotidiana o feliz de un personaje rara vez son objeto de narraciones o noticias de primer orden.
} 
de las Torres Gemelas del Word Trade Center de Nueva York por un grupo terrorista. E1 primero de estos eventos de la historia americana ocurre cuando Alack Sinner tenía entre siete y ocho años de edad ${ }^{8} \mathrm{y}$ en el segundo alrededor de sesenta y cuatro años.

En la mayor parte de los capítulos, no se cita una fecha para determinar cuando suceden los hechos narrados, pero sabemos aproximadamente cuando se desarrollan por citas sobre personajes de la época — especialmente los presidentes de la nación-, por carteles en la ciudad o por la prensa. Un ejemplo de este último medio lo vemos en el episodio «Como un rey mutilado»: un periódico, llevado por el viento, se estrella contra la ventana del dormitorio de Sinner; en la portada aparece la noticia del asesinato de John Lennon el 8 de diciembre de 1980. A partir del episodio «Nicaragua» aparecen, esporádicamente, fechas concretas en determinados pasajes, pero es en el de «El caso USA» donde la división temporal de los sucesos está completamente detallada.

\section{El contexto espacial}

La mayor parte de la obra se desarrolla en la ciudad de Nueva York, que los autores conciben como un Buenos Aires disfrazado. ${ }^{9}$ Alack Sinner se desplazará, puntualmente, a otras ciudades americanas y en una ocasión visitará Paris.

«La dicha parece beneficiar a los habitantes de países prósperos donde la democracia es sólida y las libertades personales son respetadas». ${ }^{10}$ Esta afirmación del psiquiatra Rojas Marcos no parece aplicable a la ciudad de Nueva York que nos describen Muñoz y Sampayo. En el capítulo "Ciudad sombría», Alack Sinner trabaja de taxista y nos hace partícipes de que para vivir en Nueva York es necesario no asombrarse de nada: «algunos prefieren no mirar [la parte oscura de la ciudad], yo no tengo elección».

Un área metropolitana de las dimensiones de Nueva York permite la convivencia de una gran variedad de personas, en cuanto a origen y costumbres, preservando su propia identidad; esta heterogeneidad humana se muestra en muchas de las viñetas de esta obra. El autor de cómics Lorenzo Mattoti pone de manifiesto que las viñetas de Muñoz son ventanas que «no se limitan a reflejar la trama del relato, sino que lanzan continuamente otros mensajes. Cada viñeta es una ventana sobre el mundo que rodea a la trama, ella le insufla aire y vida». ${ }^{11}$ Estas viñetas/ventanas muestran «miseria, violencia y cobardía, la ignorancia que triunfa representando el $80 \%$ del espectáculo cotidiano». ${ }^{12}$

8 Herody, D. (1998). «Alack Sinner: rencontre et souvenirs», en 9Art, n. 3 (1998), p. 29.

9 Imparato, L.; Ouvrard, P. y Zuccato, G. «Recordando», en Les Collectionneur de Bandes Dessinées, n. ${ }^{\circ}$ 54 (1987), p. IV.

10 Rojas Marcos, L. Op. cit., p. 122.

11 Matтoti, L. «Les fenêtres de Muñoz», en 90 Art, n. o 3 (1998), p. 47.

12 Imparato, L.; Ouvrard, P. \& Zuccato, G. Op. cit. 

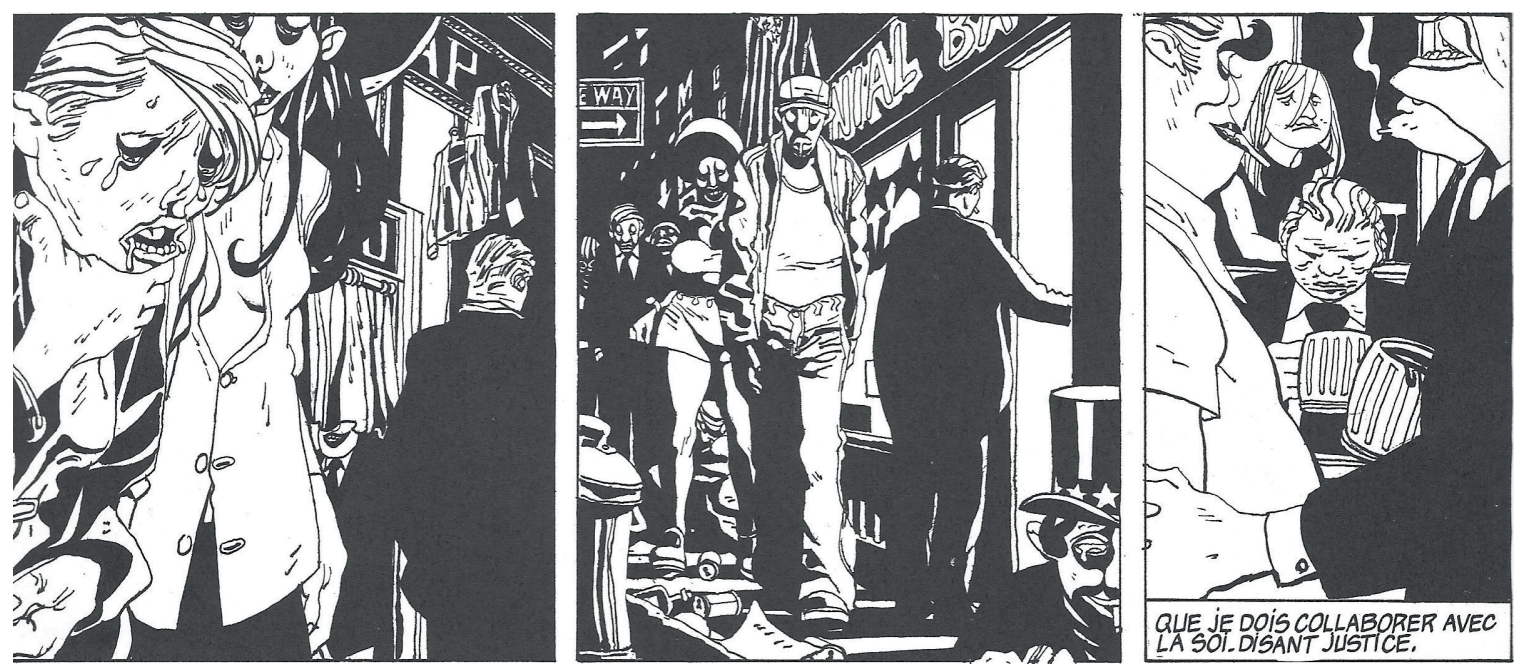

FIG. 1. Las viñetas de Muñoz son ventanas que no se limitan a reflejar la trama del relato sino que lanzan continuamente otros mensajes (Flic ou privé, Casterman, 1983, p.108).

Según Rojas Marcos, las ciudades dan más posibilidades de ser felices y realizarse que las zonas rurales donde la gente vive más condicionada por estrictas normas de conducta. ${ }^{13}$ Alack Sinner, por una parte, percibe cierta tristeza cuando se pasea por las calles de Nueva York sin conocer a nadie, pero por otra parte manifiesta que él «sería incapaz de vivir en otro lugar». El argumento que expone para justificar su arraigo a la ciudad es que «cuanto más violenta se vuelve mi ciudad más la amo. Es un sentimiento contradictorio que me permite vivir» (episodio: «Ciudad sombría»). No cabe duda de que este razonamiento no es el paradigma de la felicidad.

\section{La familia nuclear ${ }^{14}$}

La familia es el entorno en el que los niños van a establecer las primeras relaciones afectivas que son fundamentales para su desarrollo emotivo y que establecen la base para experimentar la felicidad. El modelo de familia que la sociedad trata de transmitir se inspira en conceptos como el amor, la comprensión, la seguridad o la protección que reciben los niños, pero este modelo ideal no siempre se cumple y la familia de Alack Sinner es un buen ejemplo.

Los conflictos, la intolerancia o la violencia no son ajenos a la vida cotidiana de muchas familias en las que las relaciones entre sus miembros son complejas. Alack Sinner nace en un barrio pobre de Nueva York y crece en un medio social y cultural que no contribuye al

\footnotetext{
13 Rojas Marcos, L. Op. cit., p. 219.

14 El concepto familia nuclear contempla exclusivamente a los padres e hijos. Existen otros tipos de familia como la familia extensa, la monoparental, ensamblada, homoparental o la familia de padres separados.
} 
desarrollo de individuos con valores e ideales elevados. E1 núcleo familiar de Alack Sinner está compuesto por sus padres, una hermana, Tony, ${ }^{15}$ y Alack Sinner como hermano mayor.

\section{La figura materna}

La madre de Alack Sinner apenas está presente en la obra. Físicamente se la ve en tres viñetas del episodio «Rehenes», y en otras dos, transfigurada en pez, en el de «Recuerdos». En una secuencia de «Rehenes», Alack Sinner rememora lo que sucede en su barrio en el día en que se produjo el ataque de Pearl Harbour. Él tenía entonces ocho o nueve años y asiste a la acción violenta que vecinos americanos llevan a cabo contra los vecinos japoneses que residen en su barrio. El padre de Alack Sinner comparte esta exaltación patriótica y actúa como agitador en el arresto, en nombre del gobierno de los Estados Unidos, de la familia de un compañero de juegos de Alack Sinner. El no entiende la arenga patriótica de su padre contra la familia de su amigo y pide ayuda a su madre, ella guarda silencio y no se enfrenta a su marido.

Al margen de esta secuencia, apenas sabemos nada de la vida de la madre de Alack Sinner, toda la información que aparece en la obra se concentra en una sola viñeta del episodio «Conversación con Joe»; en ella Alack Sinner le cuenta a su amigo Nick que su madre fue abandonada por su marido y que ejerció la prostitución cuando él aún era un niño. Más adelante, en el episodio «Recuerdos», vemos que el nivel de vida de la familia, bajo la tutela materna, ha mejorado notablemente.

Finalmente, se cita la muerte de la madre de Alack Sinner en el episodio «Pisa’s Motel». Curiosamente el autor de esta cita es el padre de Alack Sinner; le confiesa a su hijo que se enteró del fallecimiento de su ex mujer un año más tarde de que este ocurriera. Alack Sinner le increpa de forma abrupta preguntándole: «¿Crees que no lo sabía?». Este detalle narrativo contribuye a forjar la idea del escaso valor que la figura de la madre tiene para Alack Sinner, ella le aportó el sustento en la infancia y juventud, pero permanece como madre ausente en los recuerdos de su hijo.

El olvido de la figura materna se contrapone con la importancia que Alack Sinner da a su propia paternidad y cómo se esfuerza por estar presente, como padre, en la infancia de su hija Cheryl, que conoce cuando esta tenía cuatro años, como veremos más adelante.

\section{La figura paterna}

En el episodio «Como un rey mutilado», Alack Sinner se mira en un espejo y ve que cada día se parece más a su abuelo, pero que sus rasgos faciales son muy distintos a los de su pa-

15 Tony es un personaje secundario importante que no será abordado en este trabajo por no interferir en la percepción de la felicidad de su hermano, Alack. Sin embargo, es de destacar su experiencia sobre la felicidad bajo el efecto de la sumisión que ocurre en el episodio «Historias privadas». 
dre. Alack Sinner sabe que esta diferencia no solo es física sino que también se extiende a la forma de ser y de entender la vida.

El carácter agreste del padre de Alack Sinner cuando era joven y su larga ausencia del hogar familiar no le impiden a Alack sentir la «demanda paterna». Así, después de una larga separación va a visitarle a Bangor (Maine) donde trabaja en un motel de baja estofa (episodio: «Pisa's Motel»).

Alack Sinner no ve en su padre a un rival del que quiera deshacerse, lo que le acercaría a una especie de complejo de Edipo, ni tampoco desea el regreso de un padre-héroe, que le acercaría al personaje homérico de Telémaco en la Odisea.

El filósofo y psicoanalista Massimo Recalcati describe el complejo de Telémaco como la demanda del padre:

[no como] poseedor de la última palabra sobre la vida y la muerte, sobre el sentido de bien y del mal, sino solo un padre radicalmente humano, vulnerable, incapaz de decir cuál es el sentido último de la vida, aunque sí capaz de mostrar, a través del testimonio de su propia vida, que la vida puede tener sentido. ${ }^{16}$

Un hombre manco, que acompaña a Alack Sinner en su viaje a Bangor, le dice que él realmente no va a visitar a su padre, "que habrá perdido hasta su propia sombra», sino que es a él mismo a quien va a buscar. No cabe duda de que, desde este punto de vista filial, Alack
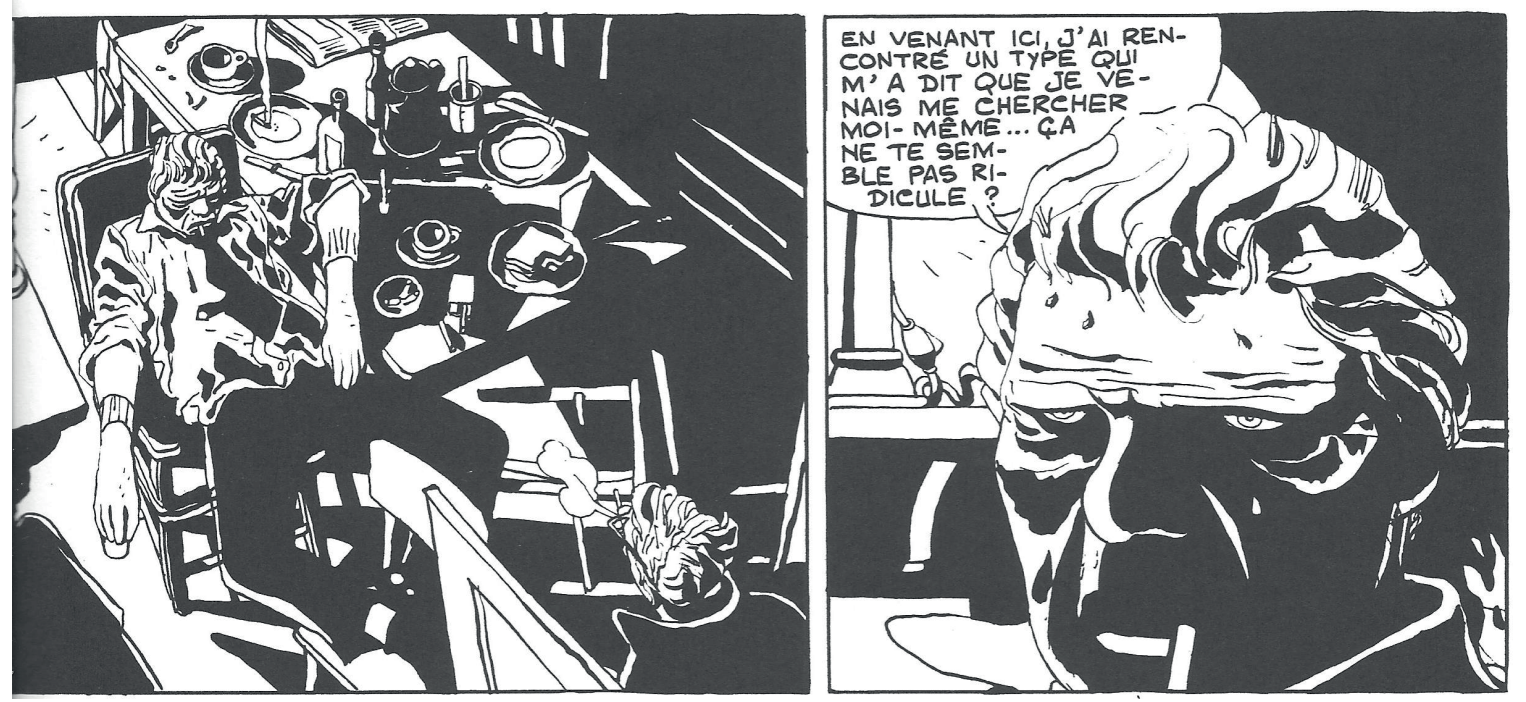

FIG. 2. Alack Sinner no encuentra en las palabras de su padre un legado capaz de humanizar su vida (Rencontres, Casterman, 1984, p. 24).

$\overline{16}$ Recalcati, M. El complejo de Telémaco, Barcelona, Anagrama, 2014. 
Sinner estaría más cerca de Telémaco que de Edipo; pero él no otea el horizonte esperando ver las velas del barco de su padre, Ulises, que regresa de la guerra de Troya, sino que va a visitarle para recibir ese «testimonio paterno» que le muestre que la vida tiene sentido.

El padre de Alack Sinner no es Ulises, no tiene un reino que dejar en herencia a su hijo ni un testimonio que contarle. Solo es un viejo miserable, que lleva un motel-burdel y que es incapaz de entender las preguntas de su hijo. Alack Sinner no encuentra en las palabras de su padre un legado capaz de humanizar su vida. La única de sus preguntas que obtiene respuesta, tras una fuerte presión, es:

Alack Sinner: ¿Qué es lo que te habría gustado que yo estudiara [que yo fuera]?

Padre: No como yo: un don nadie, un fracasado...

Durante la visita se entabla una fuerte discusión entre padre e hijo: Alack Sinner reconoce la inutilidad del viaje hacia su padre. Al no encontrar el testimonio paterno que buscaba, emprende el retorno a Nueva York sin despedirse.

No es de extrañar que Alack Sinner, en el episodio «Recuerdos», cuando ve que dos peces de su pecera se transfiguran en sus padres y le piden que se vaya con ellos, tire a los padres/peces por el retrete. Este gesto escenifica que la familia nuclear no es el entorno en el que Alack Sinner pudiera encontrar la felicidad.

\section{El trabajo como realización personal}

«Con el sudor de tu rostro comerás pan hasta que vuelvas al suelo, porque de él fuiste tomado» (Génesis, 3:19). Esta frase de la Biblia ha hecho que durante mucho tiempo la humanidad considerase al trabajo como un castigo; sin embargo, en la actualidad, para mucha gente el trabajo representa un medio para dar sentido a su vida, en el que los logros personales se traducen en alto grado de satisfacción y felicidad.

Para el desarrollo de un trabajo gratificante es necesario tener una formación adecuada, cultura general y buena educación. En el episodio "Como un rey mutilado» un personaje describe a Alack Sinner como un hombre «bien educado, que da las gracias, pide permiso, cede el paso", pero algunos indicios señalan que su cultura es limitada: si bien conoce el cuadro Guernica de Pablo Picasso, ${ }^{17}$ obra que se representa parcialmente en numerosas viñetas del episodio "Constancio y Manolo», confiesa de forma irónica que «de pintura conozco tanto como Ford» (presidente de los Estados Unidos, 1973-1974); tampoco sus conocimientos de geografía parecen notables cuando, en el episodio «La vida no es

17 El Guernica estuvo expuesto desde 1940 hasta 1981 en el Museo Metropolitano de Nueva York. Es curioso que Alack Sinner cite el cuadro a un joven español, que desconocía la existencia de la obra, cuya familia procedía de Guernica y se había exiliado después de la Guerra Civil Española. 
una historieta», intenta localizar a Argentina y pregunta: «Se encuentra cerca de Méjico, ¿no?».

A lo largo de su vida Alack Sinner ejerce varios trabajos: primero policía, luego detective privado, más tarde taxista y finalmente vuelve a su despacho de detective. Si bien el trabajo de taxista es, a priori, rutinario, los de policía y detective privado suponen un reto para las cualidades físicas y mentales que, añadido a la situación de riesgo, puede dar lugar a momentos de realización profesional.

\section{El trabajo de policía}

Alack Sinner consideraba que la policía es un cuerpo que presta un servicio público de protección y auxilio, que respeta los derechos de los ciudadanos y que solo hace uso de la violencia cuando es estrictamente necesario. Sin embargo, el ejercicio de la profesión en la ciudad de Nueva York le hará cambiar de opinión, como reflejan algunas de sus reflexiones: «Los policías buenos y malos, los verdaderos y los falsos policías. Los policías de corazón y los policías de oficio... Yo he sido uno de ellos. Es algo a lo que no se puede escapar como si de nada se tratara. Una condición que se nos impone y que estamos forzados a aceptar para sobrevivir.» (Episodio: «Ciudad sombría»); o en la que manifiesta que para los policías «justicia no es una palabra que invite a la reflexión, sino a la acción.» (Episodio: «Viet blues»).

El desencanto de Alack Sinner en su etapa como policía, narrado en el episodio «Conversación con Joe», se debe a la cruzada emprendida por sus colegas para imponer la ley y el orden en el distrito de su jurisdicción, que provocaría auténticas masacres con total impunidad. Pese a que la población, en general, aprobaba estos métodos violentos, Alack Sinner los denuncia a sus superiores, pero no recibe ningún apoyo; es más, a causa de esta denuncia sufre un acoso laboral insoportable por parte de sus compañeros. El jefe de policía le exhorta a aceptar la utilización de los «criterios personales» de sus colegas, en la aplicación de la ley, ya que con los «criterios de la democracia» no es posible establecer el orden; este llega al colmo del cinismo cuando se permite plantear a Alack Sinner un dilema: «i[Es usted] un inocente mongoloide o un loco?». Alack Sinner es relevado de sus funciones y relegado al puesto de guarda de garaje, luego trabajará de ayudante en la morgue y finalmente presentará su dimisión como policía.

\section{El trabajo de detective privado}

En su etapa como detective, Alack Sinner resuelve casos de cierta importancia en los episodios «El caso Webster» $\mathrm{y}$ «Fillmore». En este periodo de su vida, Alack se relaciona con la clase alta neoyorquina cuyo trato frío y distante le hace sentir incómodo, por lo que la trata de forma cínica y sarcástica, como muchos detectives de la literatura y el cine americanos. ${ }^{18}$

18 Reggiani, F., \& Von Sprecher, R. H. Op. cit. 
Alack Sinner también acepta clientes menos pudientes: un pastor protestante en el episodio «Él cuya bondad es infinita» o una joven inmigrante polaca en el de "Chispas»; además, trabaja de modo desinteresado para un pianista drogadicto (episodio: «Viet blues») o para vecinos de su vivienda (episodio: «Constancio y Manolo»).

Como detective privado, Alack Sinner debe colaborar con la justicia como institución pero él desconfía de su aplicación, como lo pone de manifiesto en el episodio «Constancio y Manolo»: «Yo debo colaborar con lo que llaman justicia, incluso si pienso que en la mayoría de los casos, de justicia solo tiene el nombre».

Si bien el trabajo de detective podría aportarle cierta satisfacción, tanto por resolver casos que requieren poner a prueba su capacidad física y su inteligencia deductiva (satisfacción personal), como por contribuir a la felicidad de gente que es incapaz de solucionar problemas complejos (satisfacción a través del otro); sin embargo, esta satisfacción se ve empañada por los daños colaterales que entraña realizar investigaciones en un medio hostil. Por una parte, Alack Sinner es el objeto que recibe el daño: es encarcelado en el episodio «La vida no es una historieta», o es sometido a terribles torturas en «Viet Blues». Por otra parte, él es el sujeto que causa el dolor: si bien es cierto que Alack Sinner ha tenido que defenderse de sus atacantes infringiéndoles, de forma justificada, lesiones o daños, también es cierto que ha utilizado la
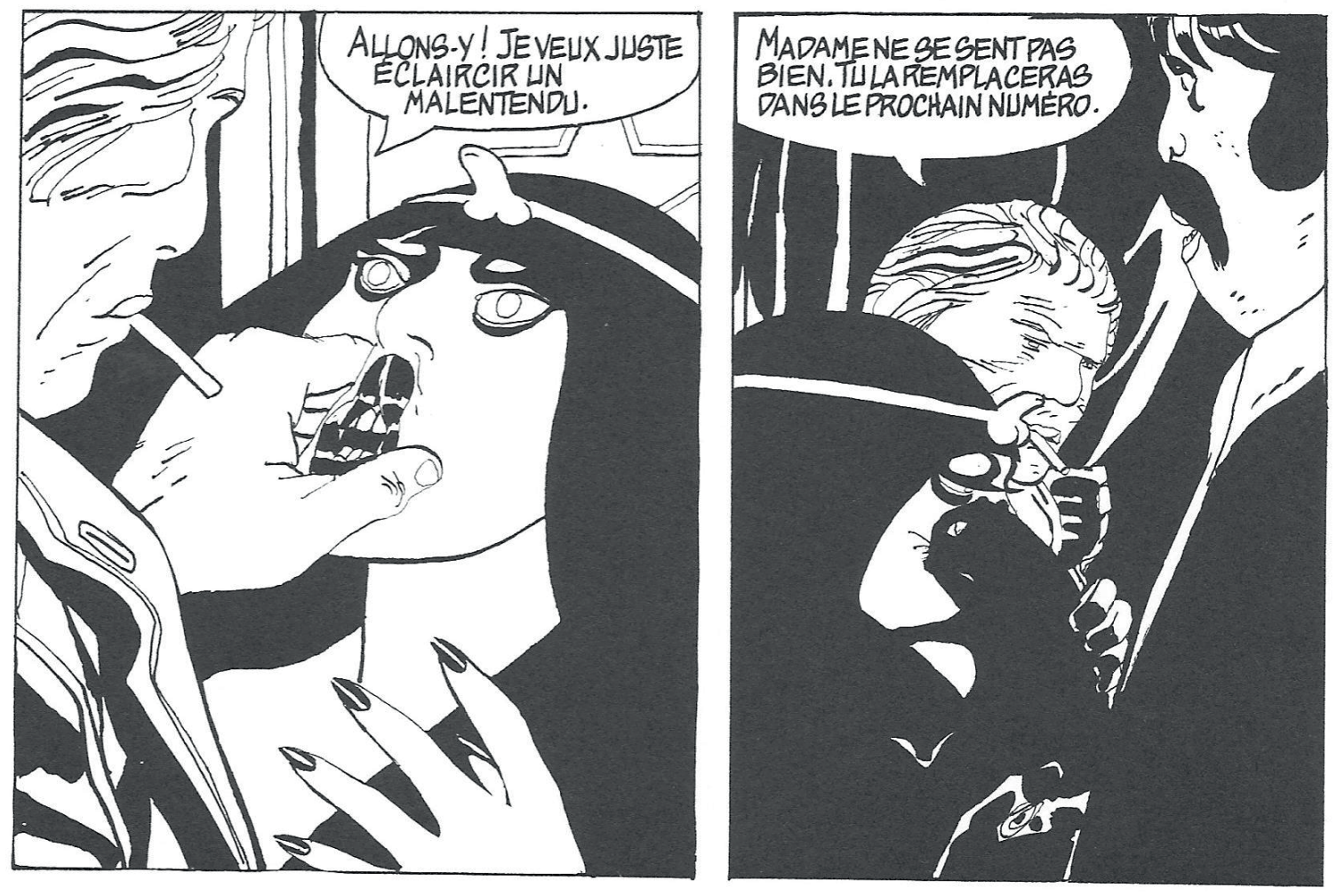

FIG. 3. Alack Sinner agrede a una cantante para conseguir sus fines («Viet blues», Casterman, 1983, p.115). 
violencia de forma gratuita, sobre individuos físicamente inferiores, con tal de conseguir sus fines (episodios: «Fillmore», «La vida no es una historieta», «Chispas», «Viet blues»).

\section{El trabajo de taxista}

Alack Sinner no se considera un auténtico taxista sino alguien que conduce un coche. En este periodo, su vida se vuelve rutinaria: «me levanto cada día a la misma hora, orino, me lavo los dientes, tomo café, leo el periódico y luego me voy a trabajar». (Episodio: «Ciudad sombría»).

La clientela de un taxista es tan variada que es una muestra representativa de la sociedad. Alack Sinner escucha a los clientes, entre la indiferencia y la apatía, no dejándose influir por sus palabras o por los sucesos que ocurren, aquí o allí, durante el trayecto. Alack Sinner es un taxista tan sui generis que no duda en expulsar del coche a un cliente, en medio del trayecto, porque la conversación no le es grata (episodio: «Ciudad sombría»).

\section{El amor existencial}

«El amor solo es posible cuando dos personas se comunican entre sí desde el centro de sus existencias, por lo tanto, cuando cada una de ellas se experimenta a sí misma desde el centro de su existencia». ${ }^{19}$ Desde este punto de vista, la solución a los problemas existenciales es la fusión con otro ser: el amor.

Para que las parejas progresen en una relación feliz deben preservar una serie de cualidades: honestidad, tolerancia, respeto a la individualidad etc., además, es necesaria la adaptación hacia el otro, porque las parejas cambian con el paso del tiempo en función de cómo evolucione cada uno de sus miembros.

Alack Sinner es una persona solitaria, le gusta la compañía femenina pero es incapaz de establecer una relación íntima de pareja, porque esto le supone comprometerse a un modo de vida en el que tendría que ceder parte de su independencia y esforzarse en comunicar emociones que le son difíciles de expresar. Este acto de amor, la entrega desde el fondo de su ser al otro, le es ajeno y se refugia en la soledad para no tener que explorar su mundo interno y enfrentarse a sus debilidades: «He intentado mirar en mi interior, pero la intención no ha pasado de la metáfora. Incluso no he tenido la fuerza de mirar al exterior...» (episodio: «Viet blues»).

\section{Katty o una relación efímera}

El primer contacto amoroso de Alack Sinner en la obra transcurre en el episodio «Fillmore». Este se reduce a un único acto sexual con una clienta muy joven de clase alta, Katty Fillmore;

19 Fromm, E. El arte de amar, Barcelona, Paidós, 1993, p.101. 
una vez consumado, Alack Sinner se siente mal y se emborracha en el bar de su amigo Joe. Este malestar se debe a que el «acto sexual sin amor nunca elimina el abismo que existe entre dos seres humanos». ${ }^{20}$ Este abismo se debe a que Alack y Katty pertenecen a dos generaciones distintas y su percepción del amor es diferente.

\section{Loretta o el refugio de la soledad}

Alack Sinner conoce a Loretta Parker en el episodio «El caso Webster» pero su relación afectiva se inicia de modo pausado y tranquilo en «Viet Blues». Ella sabe que Alack es una persona «difícil» pero está dispuesta a compartir su soledad. Es una mujer desinteresada, como demuestra el hecho de que ayude a Alack en la desintoxicación de su amigo John Smith; el tratamiento consistía en aislar al enfermo para evitar que se hiciera daño al no poder inyectarse droga. El síndrome de abstinencia lleva a John Smith a un estado mental fuera de control y a un gran dolor físico; Loretta actúa con serenidad, habilidad y no dejándose llevar por las emociones. Su «capacidad para curar» se debe, no a conocimientos terapéuticos, sino a que ella ha sufrido ese mismo tratamiento y es capaz de saber lo que siente el paciente en cada momento.
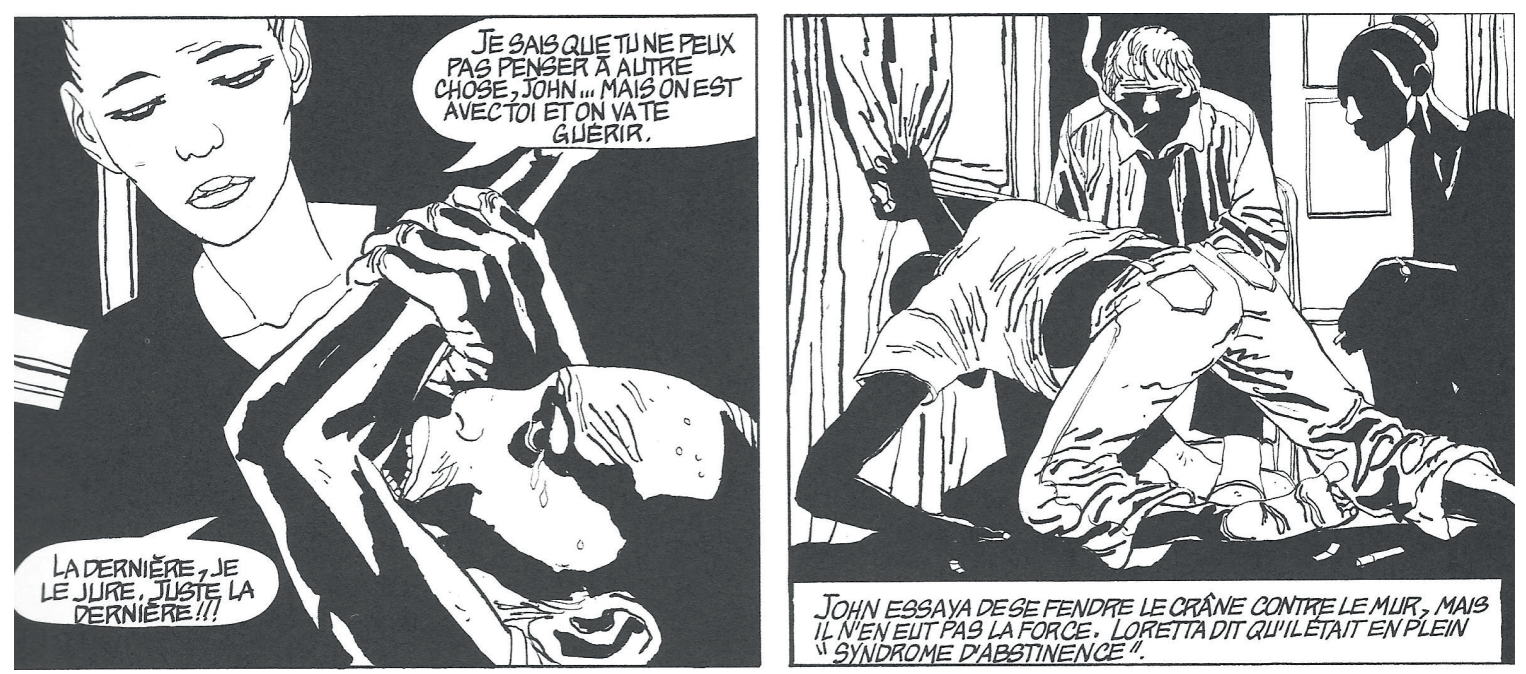

FIG. 4. Loretta Parker durante la desintoxicación de John Smith («Viet blues», Casterman, 1986, p.28).

La mirada de Loretta no transmite alegría y su personalidad podría calificarse de fría y distante, por lo que sorprende que pida a Alack el compromiso del matrimonio porque lo ama: «Tú no me amas, simplemente te sientes sola». ${ }^{21}$ La respuesta de Alack Sinner es equívoca

\section{Ibid., p.22.}

21 Alack ya había estado casado. Su mujer, Gloria, que pertenecía a la Asociación Amigos de los Combatientes, le propuso casarse por correspondencia aunque solo se conocían por foto. El matrimonio fue un fracaso por la frivolidad y el materialismo de Gloría (episodio: «Recuerdos»). 
y solo trata de salvaguardar su independencia ya que, a fin de cuentas, todo amor es solo un refugio de la sensación de soledad, una fusión con el otro para compartir la soledad desde el centro de su existencia.

\section{Enfer o el miedo a amar}

$\mathrm{El}$ amor entre individuos de grupos raciales distintos supuso enfrentarse al rechazo social y a la marginación durante siglos. Hoy los países occidentales, como sociedades más abiertas y con mayor capacidad de asimilar formas de vida no convencionales, aceptan con naturalidad las parejas interraciales.

Alack Sinner conoce a Enfer, una mujer de raza negra, en el bar de Joe (episodio: «Ciudad sombría»). La elección del nombre de Enfer parece una broma de los autores ya que Sinner es pecador en inglés y Enfer es infierno en francés.
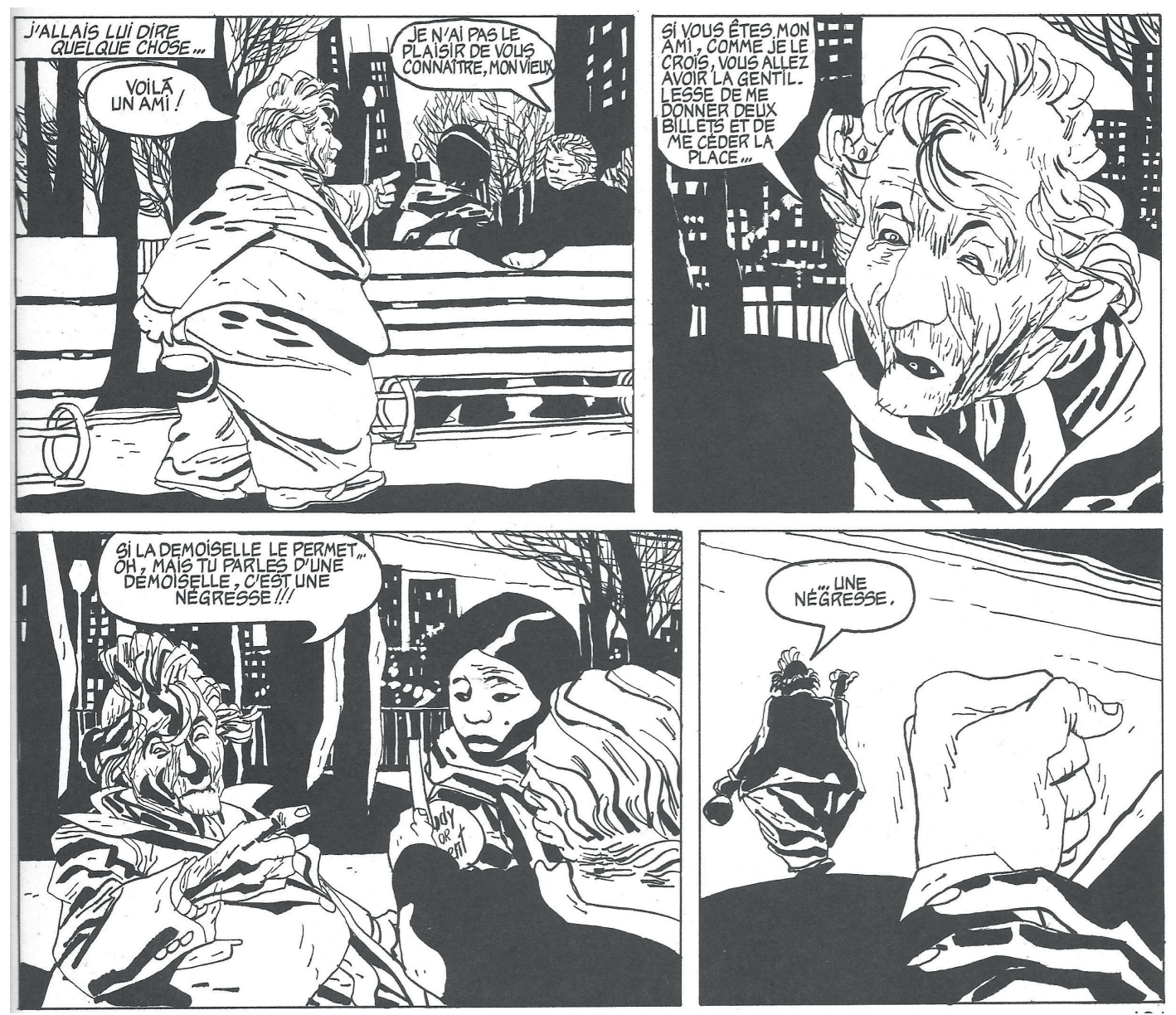

FIG. 5. Escena en la que un mendigo borracho ejemplifica el racismo americano («Flic ou privé», Casterman, 1983, p.131). 
Enfer pone a prueba los prejuicios racistas de Alack: «¿Las negras no te desagradan?... Dicen que no tenemos el mismo olor... ¿Tú me ves tan negra como soy?». Las preguntas de Enfer no son hirientes sino consecuencia del rechazo que el colectivo de raza negra ha sufrido en los Estados Unidos. Este rechazo se pone de manifiesto en la figura de un mendigo borracho de raza blanca. La escena se inicia con Alack y Enfer sentados en el banco de un parque al anochecer, a su espalda se acerca el mendigo que pide dinero a Alack y bromeando le solicita quedarse con Enfer; cuando el mendigo descubre que Enfer es negra se marcha mostrando su desprecio, por la bajeza de Alack, quizás porque lo único que le queda en la vida, para sentirse digno, es su racismo.

Enfer considera que Alack es una persona rara. Pese a ello le ama. Su relación está basada en la libertad y se permiten tener contactos sexuales con otras personas. Por su parte, Alack no puede expresarle sus sentimientos cuando ella le pregunta si la ama, porque su exhibición le provocarían una fuerte convulsión: «Yo habría podido responderle que la amaba, habría sido un simple sí... pero, ¿podría escucharme a mí mismo decir sí? Tuve miedo. Por primera vez en mi vida he tenido miedo». Este estado de angustia no es por temor a la persona en sí o al poder que ella pueda alcanzar sobre él si muestra sus debilidades; sino que pone en tela de juicio su relación con los semejantes y lo que es más difícil: la aceptación de sí mismo. Este comportamiento es descrito por Erich Fromm: «Si puedo decirle a alguien "te amo", debo poder decir "amo a todos en ti", a través de ti amo al mundo, en ti me amo también a mí mismo». ${ }^{22}$

La angustia hace que Alack entre en contradicciones con respecto a la relación con Enfer, por un lado quiere verla pero por otro le gustaría emborracharse solo; ella percibe la lucha

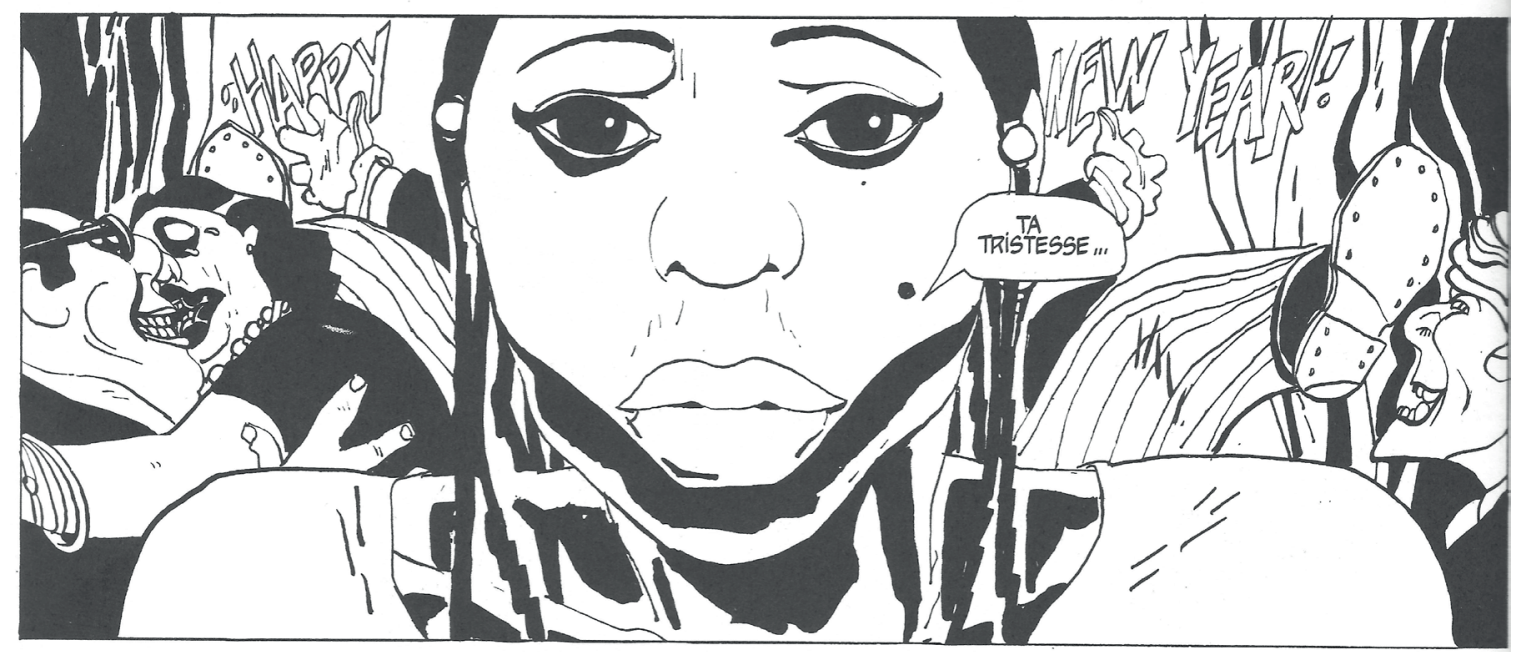

FIG. 6. Enfer pone fin a su relación Alack a causa de su tristeza. Un estado de ánimo de continua desesperanza que conduce a la soledad ( Flic ou privé», Casterman, 1983, p.146).

${ }_{22}$ Fromm, E. Op. cit., p. 52. 
interior de Alack y pese a que le gusta estar con él y le ama, no quiere verle más a causa de su tristeza. Enfer no se refiere a la tristeza como decaimiento moral motivado por un acontecimiento doloroso concreto, sino como un estado de ánimo de continua desesperanza que conduce a la soledad.

Cinco años después de la separación, Alack y Enfer se reencuentran en el bar de Joe en el episodio «Invest on love». Con la perspectiva que da el paso del tiempo, Alack puede contarle lo que sentía cuando se separaron: «Te he amado tanto que tú no puedes imaginártelo... Fue más tarde cuando me di cuenta». Ahora ya es tarde, Enfer hubiera podido hacerle feliz pero entre ellos se interpuso su tristeza. Una vez más la felicidad se mostró esquiva con Alack Sinner.

La tristeza de Alack se manifiesta por su falta de alegría. La risa es la expresión de la alegría, pero Alack no ríe y apenas sonríe como se lo hace saber Enfer en el episodio «Invest on love». Solo en una ocasión, Alack estalla en una rotunda carcajada cuando su hija, Cheryl, de ocho años de edad, es acusada de ser comunista por una profesora del colegio en el episodio «El verdadero rostro del comunismo».

La relación entre Enfer y Alack se prolongará en el tiempo, pero no como pareja sino a través de su hija, Cheryl. ${ }^{23}$ Alack conocerá la existencia de la niña cuando ya tenía cuatro años. En su reencuentro, Enfer le dice que es madre, pero Alack no se atreve a preguntar quién es el padre. Después de emborracharse en la fiesta que Nick celebrara, en compañía de sus colegas policías, con motivo de su próximo segundo matrimonio, Alack reúne el valor suficiente para telefonear en la noche: «Enfer... Enfer... Es tarde, disculpa... Enfer... ¿Quién es el padre de tu hija?». La voz al otro lado del teléfono contesta: «Tú».

La alegría y la felicidad que produce la paternidad le es postergada a Alack porque él no se interesó por la vida de Enfer o más bien no se atrevió a llamarla o a preguntar por ella. Pero esta pérdida temporal de felicidad se va a prolongar aún más porque el destino le tiene guardada una mala pasada en el episodio «El teniente de policía Randy Rademaker».

Cuando Alack quiere disfrutar de ese momento de felicidad y desea reconciliarse con el mundo por su paternidad, se ve obligado a matar, en defensa propia, a un antiguo colega policía, Rademaker, que siempre le había odiado por considerarle comunista y por haber denunciado la «cruzada» policial que citamos anteriormente. Esta muerte llevará a Alack Sinner a la cárcel, le crea la angustia de poder ser condenado a la silla eléctrica y, por lo tanto, de no conocer a su hija Cheryl. Si la felicidad fuera un lugar, Alack Sinner parece caminar en dirección contraria.

\section{Delia o la felicidad como ideal político}

En 1981 Ronald Reagan es nombrado presidente de los Estados Unidos. Su ideología neoliberal tenía un alto componente anticomunista y creía que los movimientos de liberación

23 Cheryl es la canción de Charlie Parker que sonaba en el bar de Joe cuando Alack y Enfer se conocieron. 
en Centroamérica estaban financiados por la URSS. Así apoyó a gobiernos autoritarios en El Salvador y Guatemala y organizó una política de aislamiento de Nicaragua por tener, tras la revolución popular sandinista (1979-1990), un gobierno de ideología próxima al comunismo.

El gobierno de Nicaragua acusó a Estados Unidos, ante la Corte Internacional de Justicia de la ONU, por violación del derecho internacional al apoyar a grupos armados (los contras) que hacían la guerra en el país. ${ }^{24}$

Alack Sinner solo conocía el conflicto de Nicaragua contra Estados Unidos por los encendidos discursos de Ronald Reagan y por la campaña mediática que presentaba a Nicaragua como un peligro para la nación; sin embargo, se preguntaba: «Cómo un país tan minúsculo puede representar una eventual amenaza para Estados Unidos».

En este contexto histórico, Alack conoce a Delia, una empleada consular de Nicaragua, con la que trabajará para evitar el hipotético atentado contra un ministro nicaragüense en visita a Estados Unidos en el episodio «Nicaragua».

Al principio, la relación entre Delia y Alack es meramente profesional y él no sabe cómo tratarla por la diferencia de edad, cultura y carácter. Aunque luego surja el afecto, ella se siente insegura y expone sus temores, de modo semejante a como lo hiciera Enfer — « $\mathrm{i} \mathrm{Te}$ gustan las mujeres latinas?»-, o sus complejos de ser latina — «Y tu hija, ¿qué pensará de mí?»- ¡ ¡Delia no sabía que Cheryl era de raza negra! (episodio «Nica la encantadora»).

Delia está políticamente implicada con el movimiento sandinista y quiere que Alack le acompañe a Nicaragua, pero él no está lo suficientemente comprometido con ella, como lo demuestra la conversación que sostienen, de forma indirecta, con la intermediación de Cheryl: «¿Amas a mi padre?». Delia no lo duda: «Sí por supuesto que le amo», «字Y tú, Alack, tú la amas?». No hay respuesta.

Delia regresa a su país con la esperanza de que Alack vaya, más adelante, a vivir con ella a Nicaragua. Esta pretensión no es tan ingenua como parece porque Alack reconoce, al final del episodio «El verdadero rostro del comunismo», que había empezado a amarla.

La felicidad también puede alcanzarse en la lucha por ideales políticos. Alack Sinner puede trabajar de forma desinteresada por la causa nicaragüense y cuando le preguntan el porqué, él contesta: «Un conjunto de ideas estúpidas». La felicidad como ideal político no entra en los principios vitales de Alack Sinner, más bien es lo contrario, pues nunca ha creído que los políticos busquen la felicidad de los pueblos como lo atestigua su conclusión final: «Nicaragua se había convertido en la dictadura comunista que Reagan pretendía que fuera, aunque antes no lo era».

24 Pese a que la Corte sancionó a Estados Unidos en 1986 y que la ONU presionó para que pagaran una cuantiosa multa, Estados Unidos ni aceptó la decisión de la Corte ni pagó la sanción. 


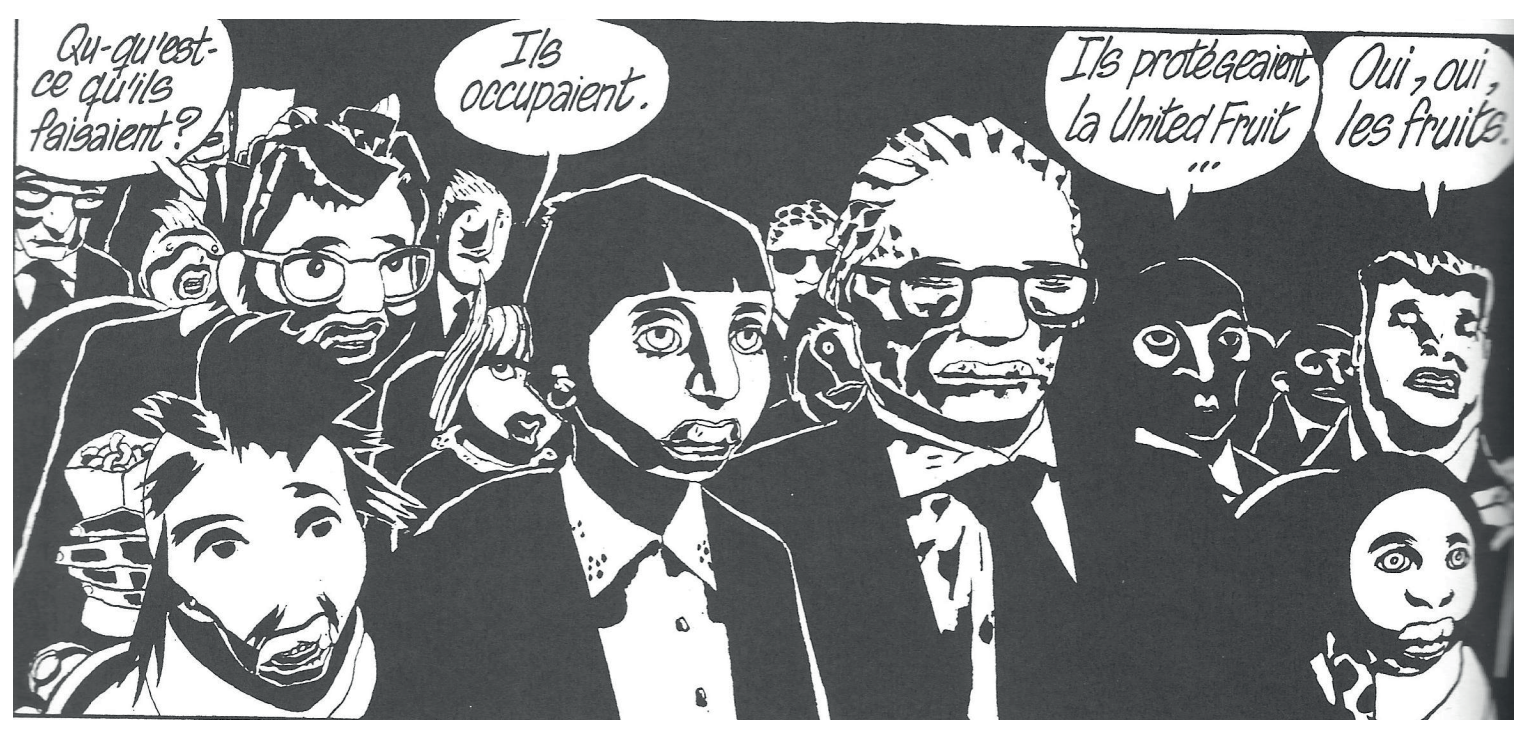

FIG.7. Delia, Alack y Cheryl, a los ocho años, asisten a una representación de títeres de gran contenido político («Nicaragua», Casterman, 1988, p.50).

\section{Sophie o la independencia en el amor}

Si hay una mujer por la que Alack Sinner haya sentido algo más que afecto, esta es sin duda Sophie Milasewicz. ${ }^{25}$ Ella, una emigrante polaca, es la única persona a la que Alack Sinner podía contarle cosas que no le había contado a nadie: «Yo le hablaba de mí» y a la única con quien podía tener un gesto de ternura: besarla mientras duerme (episodio: «¿Por qué me dejaste?»).

Sophie, de joven, creía que el mundo pronto desaparecería a consecuencia de la acción del hombre y quería contribuir a su destrucción provocando incendios en la ciudad de Nueva York (episodio: «Chispas»). Luego, de mayor, abandonará la ciudad y se instalará en un pequeño pueblo en el que disfrutará de una favorable situación económica por regentar una gasolinera; una ironía del destino para una antigua pirómana.

En el episodio «El final del viaje», Alack se desplaza al pueblo donde vive Sophie. Allí pasa unos días en compañía de su amiga y de sus dos hijos pequeños. Alack hace una vida familiar convencional pero satisfactoria ya que, aunque no sea su propia familia, con ellos experimenta algo parecido a la felicidad.

Alack y Sophie compartirán sus sentimientos, se ayudarán mutuamente y se protegerán contra miedos y temores, pero no vivirán juntos porque su relación está basada en la independencia (episodio: «Historias privadas»).

25 Sophie también aparecerá en un episodio de la serie El bar de Joe. Además, es la protagonista de un libro bajo su propio nombre. 


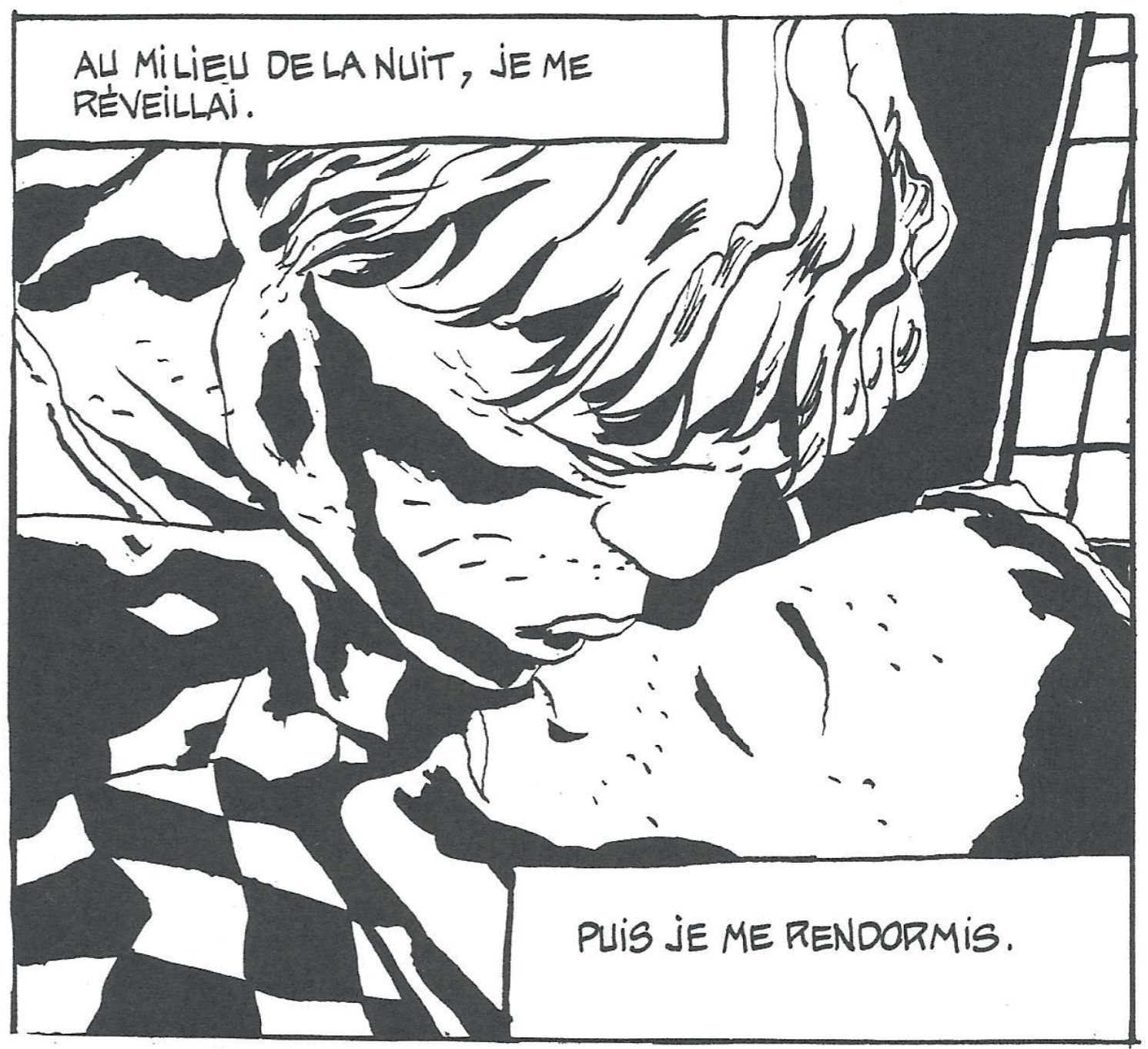

FIG. 8. Alack besa a Sophie dormida. Un gesto de ternura cercano al amor («Rencontres», Casterman, 1984, p. 107).

\section{Tres generaciones y tres guerras}

Alack Sinner, su padre y John Smith pertenecen a tres generaciones distintas que participaron en conflictos bélicos. El padre de Alack Sinner estuvo con los marines durante la larga ocupación estadounidense de Nicaragua (1912-1933, con una interrupción de nueve meses entre 1925 y 1926); Alack Sinner participó en la guerra entre Corea del Sur, apoyada por Estados Unidos, y Corea del Norte (1950-1953) y John Smith fue enviado al conflicto vietnamita (1955-1975) en el que Estados Unidos trató de impedir la reunificación del país bajo un gobierno comunista.

Estos tres personajes tienen una visión distinta de su experiencia en el campo de batalla. Así, el padre de Alack manifiesta cierto orgullo de haber participado, con los marines, en la lucha 
contra el comunismo en Nicaragua. Sinner no comparte este entusiasmo cuando comenta: «Nicaragua, la casa de Delia. Hasta ahora yo no había oído hablar de ese país donde mi padre había estado y donde había hecho el mal» (episodio: «El verdadero rostro del comunismo»).

Para John Smith, la guerra de Vietnam fue una experiencia terrible, en la que tuvo que asistir a actos crueles, que le marcaron emocionalmente y le condujeron a un proceso de autodestrucción, a través de las drogas, y a la merma de sus capacidades como músico. Alack Sinner transforma esta realidad en la forma poética de la ensoñación: "Yo soñé que John Smith tocaba [el piano] de nuevo como antes. Yo soñaba sistemáticamente, hasta que me puse a soñar que yo soñaba» (episodio: «Viet blues»).

No hay duda de que para Alack Sinner la participación en la guerra de Corea no fue un motivo de orgullo, como el manifestado por su padre, pero tampoco tuvo las consecuencias tan traumáticas como las de John Smith. No sabemos cómo afectó la contienda al joven Alack Sinner porque hay pocas referencias al respecto en la obra. Seguramente no salió indemne: fue herido en el frente, pero moralmente tuvo la satisfacción de salvar a su amigo Nick; el daño físico no es comparable al daño emocional ya que, probablemente, la guerra enterró su juventud y le hizo perder la inocencia y desarrollar la desconfianza en el ser humano. Esta separación entre el joven Alack y el adulto Sinner se pone de manifiesto cuando pregunta a su padre: «¿Cómo era yo antes de la guerra? ¿Cómo me veían los otros, tú?» (episodio: «Pisa's Motel»). El paso por Corea le ha borrado de la memoria una parte de sí y de la felicidad que quizás nunca tuvo.

\section{Cheryl o la relación padre e hija}

Hasta la edad de tres años, las hijas tienen una relación muy especial con su padre, ya que él representa la masculinidad más próxima frente a su propio género y, probablemente, sea el modelo que marcará su futura relación con los hombres.

Cheryl, criada por su madre (Enfer) y su tía (Phoebe), conoce a Alack Sinner cuando tiene cuatro años, pero no lo reconoce como progenitor: «Mi padre eres tú (Enfer) y la tía. É1 no», dice en el episodio «Cheryl, tesoro». La paternidad crea en Alack Sinner sentimientos contradictorios: «Yo quiero estar con ellas y estar solo, porque yo he aprendido a estar solo y ellas juntas... Un mundo con el que debo armonizarme». Él quiere ser aceptado por su hija, pero no es fácil, porque no han pasado juntos la etapa en la que el padre representa todo para su hija y porque hay una enorme distancia entre ellos, como bien se lo hace saber Phoebe: «Tú no has vivido con ella, tú no sabes quién es. Ella es de otra raza, de otro sexo y tiene otra educación». Phoebe tiene razón, pero Alack quiere estar presente en la vida de su hija, aunque esto pueda producirle cierto temor como bien detecta Enfer: «No tengas miedo de ella (Cheryl)... Los niños son a veces terroríficos».

Finalmente, Cheryl acaba por aceptar a Alack como padre; un padre que vive fuera del hogar, al que puede amenazar cuando no cumple con sus caprichos: «No quiero que seas mi 
padre»; o con quien puede mostrarse punitiva, con duras palabras, si no recibe la atención que ella cree que le es debida: «Me pregunto si los niños conocen el peso de sus palabras», se lamenta Alack.

Cuando los hijos alcanzan la adolescencia, comienzan a separarse de sus padres para enfrentarse a la vida con sus propios recursos, pero los padres siempre viven con preocupación las vicisitudes de su prole porque desean que sean felices y no ahorran esfuerzos para que así sea; sin embargo, no siempre aciertan y por exceso de protección, por sobreactuación, desconocimiento o incomprensión, pueden interferir negativamente en los planes de sus hijos. Los padres pueden estar al margen de muchas de las actividades y proyectos de sus hijos pero, normalmente, estarán disponibles para cuando ellos los necesiten, porque parte de su felicidad es serles útiles.

En el episodio «Historias privadas», Cheryl ingresa en prisión por la muerte de un hombre al que no niega haber matado, pero que tampoco afirma, explícitamente, haberlo hecho. La convivencia en la cárcel es dura y Cheryl intenta suicidarse. Este episodio constituye un reto, como detective, para Alack Sinner porque tiene que actuar bajo la presión de la angustia de la madre (Enfer) y los temores y las dudas sobre su proceder en la investigación. $\mathrm{Si}$ bien, en este episodio, la prueba de la inocencia de Cheryl y su posterior excarcelación procura una gran felicidad a Alack; en el episodio «El caso USA», por el contrario, la alegría de Alack, por la liberación de Cheryl (en avanzado estado de gestación) de sus secuestradores, se ve ensombrecida por la acritud e incomprensión de su yerno, Robert, que le acusa de ser el causante directo del secuestro y de todas las penalidades que de ello se derivaron. Es difícil ser feliz con tu hija cuando cuentas con la antipatía de su pareja, que frena los intentos de amistad y cariño que Alack le brinda: «Tú [Alack] vas a ser el abuelo de mi hijo, estoy obligado a aceptarte».

\section{La religión como fuente de felicidad}

«Las personas que alimentan creencias religiosas esperanzadoras, independientemente de su lógica o racionalidad, se sienten más satisfechas con la vida que quienes no las sustentan». ${ }^{26}$ La esperanza de una vida llena de felicidad más allá de la muerte, hace más soportable las experiencias negativas de la vida y la aceptación de las limitaciones de la existencia humana. El hecho de pertenecer a una congregación religiosa, hace que se creen sinergias, entre sus miembros, que incrementan el valor de su fe y se sientan más dichosos.

En el episodio «Él cuya bondad es infinita», Alack Sinner nos expone su punto de vista sobre la religión y los creyentes: «Yo no estoy aquí [en misa] por devoción... Ellos [los feligreses] parecen gozosos y contentos, unidos por un mismo temor [a Dios], exultantes frente a la posibilidad de salvarse de un castigo terriblemente doloroso y aún más doloroso espiritualmente». Este episodio está salpicado de breves frases que hacen pensar que Alack

$\overline{26}$ Rojas Marcos, L. Op. cit., p. 140. 
Sinner se movería, en el plano espiritual, entre el agnosticismo y el ateísmo. Desde la acción religiosa, Alack Sinner no puede disfrutar de la felicidad que se auto otorgan los creyentes en los límites de su fe. Él no puede engañarse a sí mismo, adoptando dogmas que le son ajenos, y trata de buscar la felicidad en otras utopías como la libertad, la solidaridad, o la amistad.
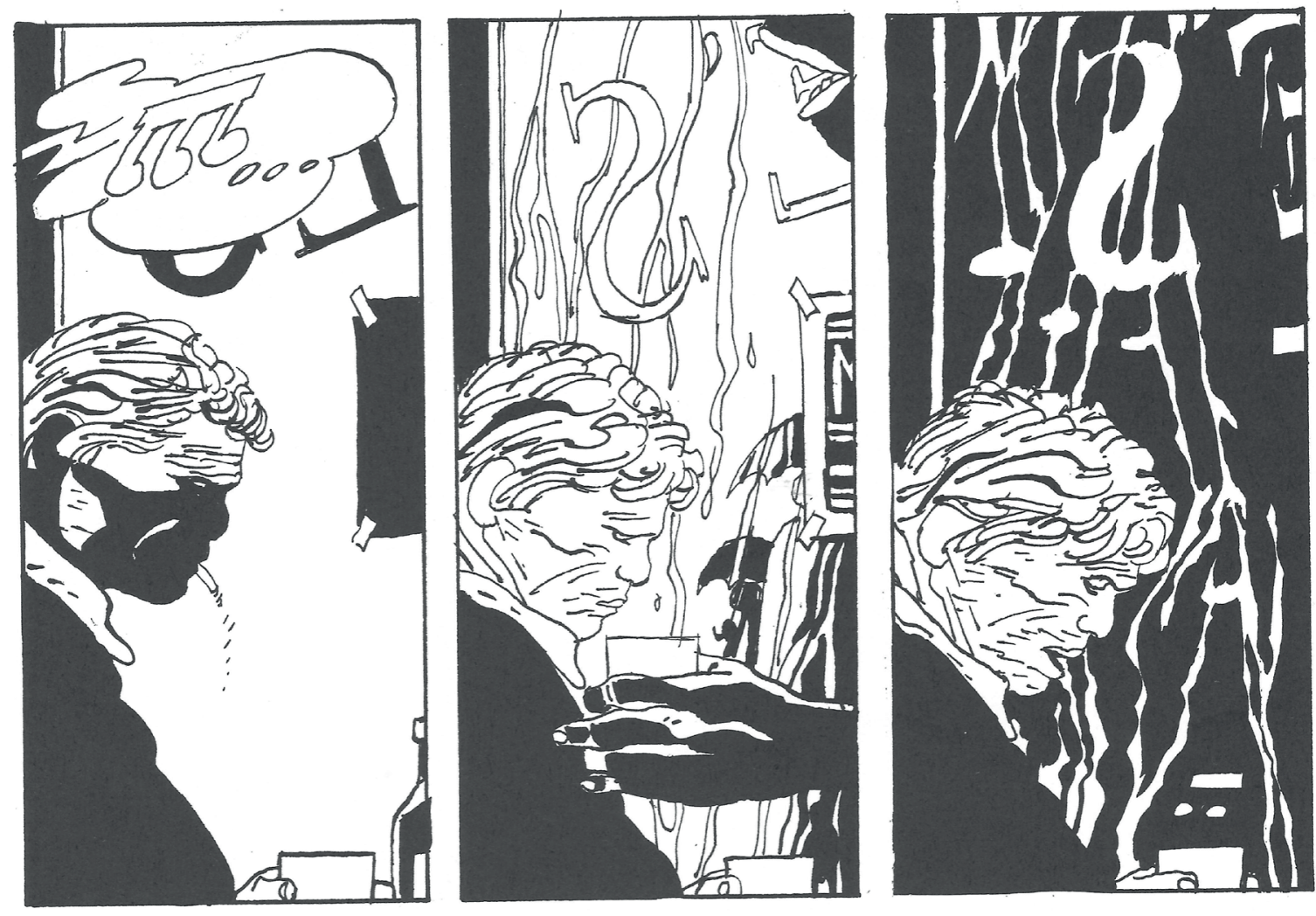

FIG. 9. Secuencia de tres viñetas que muestran el paso del tiempo, la soledad y la embriaguez de Alack Sinner («Flic ou privé», Casterman, 1983, p. 10).

\section{El alcoholismo y la salud}

Los ex combatientes tienen el triple de posibilidades de sufrir depresión y alcoholismo que las personas que no han estado en la guerra. ${ }^{27}$ No podemos establecer una relación directa entre el consumo excesivo de alcohol de Alack Sinner y su estancia en la guerra de Corea pero probablemente haya contribuido en una notable proporción. De hecho, es normal ver a Alack Sinner bebiendo solo en el bar de Joe y que la jornada culmine con una fuerte borrachera. Por eso son frecuentes las citas referidas a la soledad y el alcohol: «La primavera brota y estoy harto de mi soledad»; "Días grises pasan para mí, días de vaciar botellas...» (episodio: «Viet Blues»); «Así acaba un día que he pasado recordando hechos significativos

27 Ibid., p. 172. 
de mi existencia. Un día más, un día feliz y solitario. Yo me he emborrachado... he tomado una ducha, ¿qué más se puede pedir en la vida?» (episodio: «Recuerdos»). Hasta su padre le dice que es «un loco... un borracho, un enfermo... un mal hijo» («Pisa’s Motel»). E1 consumo de alcohol produce un estado inicial de euforia, pero luego lleva a la tristeza que conduce a la infelicidad.

Con la edad, Alack Sinner empieza a tener problemas de salud, a causa del alcohol, el tabaco y la vida sedentaria, y es ingresado en un hospital por disfunción gástrica en el episodio "Cheryl, tesoro»; los análisis clínicos detectan una tasa muy elevada de colesterol, riñones tocados, una gastritis aguda. Sin embargo, cuando Alack sale del hospital no hace caso del tratamiento médico y se toma un whisky en el bar más próximo (episodio: «¿Por qué me dejaste?»).

\section{¿Una vida feliz para Alack Sinner?}

En el episodio "El caso USA», Alack Sinner, ya sexagenario, cambia de hábitos de vida: hace jogging, consigue dejar de fumar y no consume alcohol. Además, tiene una situación económica desahogada: «Confieso tener algunas alegrías... algunas razones para pensar en la dulzura de los días y en el placer de estar con algunas personas». Esta es la primera vez que Alack Sinner expresa la alegría de vivir y esta manifestación de júbilo es percibida por los demás. En la escena final de este episodio, dos ancianos, sentados en un banco del parque, ven a Alack jugar con su nieto de tres años y comentan: «Mira a ese hombre, parece feliz». Esta observación podría ser el final, feliz, del camino que Alack emprendiera en busca de la felicidad. Todo parece indicar que los autores/padres han dejado un resquicio por el

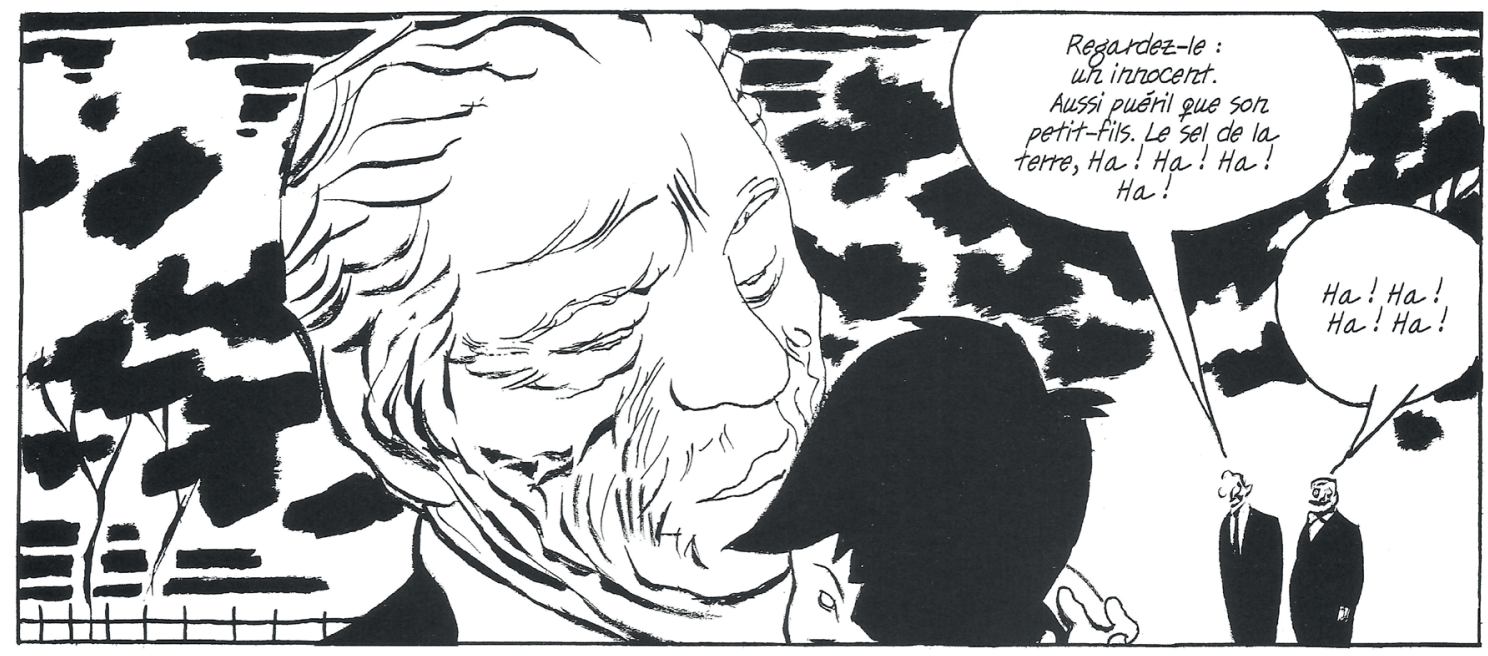

FIG. 10. Dos ancianos se ríen de la felicidad de Alack Sinner. («L'affaire USA», Casterman, 2006, p. 80) 
que Alack ha encontrado un sentido a la vida, pero la realidad es que le condenan a vivir en un mundo donde la felicidad es solo una apariencia.

Los dos ancianos del parque son la representación del poder económico y financiero que controla el mundo actual, más allá de la acción de los gobiernos y de los ciudadanos. Después de señalar la felicidad de Alack, uno de los ancianos añade: «Ese es nuestro trabajo, que ellos parezcan felices con sus hijos y sus nietos». Después de jactarse de cómo controlan y manipulan financieramente a las personas y a sus dirigentes, se ríen de Alack: «Mírale, un inocente tan pueril como su nieto. La sal de la vida». Su felicidad es reírse de la felicidad de Alack Sinner.

\section{Conclusiones}

La infancia de Alack Sinner transcurrió en un hogar inestable. Por una parte, un padre de carácter rudo, que desaparece de su infancia y que, ya anciano, es incapaz de darle un testimonio que le permita ver el sentido de la vida para la búsqueda de la felicidad, y por otra parte, una madre que solo sirve de sustento pero que es incapaz de crear recuerdos felices en la memoria de Alack Sinner.

Si a esta mala situación familiar se le añade la participación, durante su juventud, en una contienda bélica, se obtiene a una persona emocionalmente traumatizada. Su baja resiliencia le lleva a aceptar el pesimismo schopenhauriano de que la felicidad es solo la ausencia de dolor. Así, las «acciones individuales» que le pueden llevar a la felicidad no son emprendidas por Alack Sinner: su salud es frágil por el alcoholismo, el trabajo no le causa satisfacción sino que le lleva a situaciones calamitosas, la religión no es un refugio porque carece de fe, los ideales políticos le son ajenos por la desconfianza en la humanidad, el amor no es un bálsamo en su vida porque no puede expresar sus sentimientos y se refugia en la soledad.

Según Lyubomirsky, estamos condicionados por nuestro material genético para poder optar a la felicidad, pero es a través de nuestras «acciones individuales» con las que podemos alcanzarla. Como hemos visto, las acciones individuales que Alack Sinner ha ido tomando, a lo largo de su vida, no han sido eficaces para equilibrar la balanza del bienestar a su favor; él no supo entender el mundo complejo que le tocó vivir y el resultado fue la infelicidad ya que «lo que produce nuestra felicidad o desgracia no son las cosas tal y como son realmente en la conexión de la experiencia, sino lo que son para nosotros en nuestra manera de comprenderlas». ${ }^{28}$

Un caso extremo de una «manera de comprender la felicidad» se encuentra en la novela de Imre Kertësz: Sin destino. ${ }^{29}$ Cuando le preguntaban al joven protagonista por los horrores

28 Schopenhauer, A. Op. cit.

29 Kertësz, I. Sin destino. Círculo de lectores, 2002, p.90. 
de los campos de concentración nazis, en los que él había vivido, a él le hubiera gustado hablar sobre los momentos de felicidad que allí sintió porque «en los intervalos de las torturas (había habido) algo que se parecía a la felicidad».

En un contexto completamente distinto al descrito por Imre Kertësz, Alack Sinner también percibe algo parecido a la felicidad: primero, cuando convive con Sophie Milasewicz, y luego, ya sexagenario, cuando llega a interiorizar el mundo en el que vive; es solo en esa época de su vida cuando logra exteriorizar la felicidad. 


\section{Bibliografía}

Cyrulnik, B. «Nadie sabe definir la felicidad», en El País, (Abril 2016). Disponible en http://elpais. com/elpais/2016/03/22/actualidad/1458665067 836852.html.

Fromm, E. El arte de amar, Barcelona, Paidós, 1993.

Herody, D. (1998). «Alack Sinner: rencontre et souvenirs», en 90 Art, n. 3 (1998), pp. $22-29$.

Imparato, L.; Ouvrard, P. \& Zuccato, G. «Recordando», en Les Collectionneur de Bandes Dessinées, n. ${ }^{\circ} 54$ (1987), pp. 21-24.

Kertësz, I. Sin destino. Círculo de Lectores, 2002.

Lemare, T. «Muñoz: Un argentin en noir et blanc», en Zoo, n.o 11 (2008), pp. 6-8.

Manes, F. «La felicidad de todos los días», en El País, (Marzo 2016). Disponible en http://elpais. com/elpais/2016/03/20/ciencia/1458473642_576776.html.

Matтoti, L. «Les fenêtres de Muñoz», en 9o Art, n. 3 (1998), pp. 46-47.

Recalcati, M. El complejo de Telémaco, Barcelona, Anagrama, 2014.

Reggiani, F., \& Von Sprecher, R. H. «Alack Sinner: un detective degenerado». Disponible en http://www.tebeosfera.com/documentos/documentos/alack sinner_un detective degenerado. html.

Rojas Marco, L. Nuestra felicidad, Madrid, Espasa Calpe, 2000.

Schopenhauer, A. El arte de ser feliz. Barcelona, Herder editorial, 2012. 